\title{
SECURITY RISKS GENERATED BY BEHAVIOR OF RELIGIOUS FANATICS
}

\author{
Iulian DINULESCU \\ "Mihai Viteazul” National Intelligence Academy, Bucharest, Romania \\ iuliandinulescu@gmail.com \\ Cristian TRONCOTĂ \\ "Mihai Viteazul” National Intelligence Academy, Bucharest, Romania \\ prof_troncota@yahoo.com
}

\begin{abstract}
Human behavior has generated a series of threats to human security throughout history, generating major violence at the time when it was doubled by an exaggerated religiosity. Religious fanaticism has manifested itself in all societies, regardless of their forms of organization. The consequences of the phenomenon deeply marked inter-human relationships, both within the community, but especially in communities that have other religions. The article shows the characteristics of religious fanaticism and the factors that cause people to adopt such a behavior of exacerbating religious zeal doubled into intolerance towards those of opponents, both of other faiths and those within their own confession.

The issue is not generated by the religious phenomenon or religiosity that such sectarians or religious organizations and religious fanaticism have with some of the members of such religious entities. They are transformed into perfect soldiers because they respond to clergy 'requests, even with the sacrifice of their own lives, without counting for these individuals, the feelings for their own family members or the duty to support them. In such situations the phenomenon mentioned can not be prevented until it is truly understood from the religious point of view. Therefore, particular attention must be paid to the motivations that lead some individuals to such behavior, as well as to the characteristics of such religious fanatics, and to the way they create risks to human security. In this article we will only address the religious fanaticism manifested by Christianity and Islam, because these are the ones that can have an impact at European and national level. To this end, we will look at some elements of religious fanaticism that indicate this kind of behavioral pattern. After that we will clarify and show the reader the connection between religious fanaticism, the behavior of the followers influenced by this phenomenon, and the inter-human relationships determined by this type of actors.
\end{abstract}

KEYWORDS: religious fanatics, religiosity, behavior, motivations, sects

\section{Introduction}

Religious fanatics are people who exacerbate religious zeal doubled into intolerance towards others, especially those who confess confessional opponents. Religious fanatics have undergone a process of indoctrination practiced by some religious organizations so as to meet the demands of the leaders of such confessional entities. The risk to the national security of each state is that these fundamentalist individuals may in some situations be more implicated in a cause even than the military or the police, which is revealed by the fact that they have no dilemmas in sacrificing their lives for the goals set by leaders in the name of the divinity. Most leaders of such religious entities have borrowed and used 
processes already established in the success of religious confessions in geographic and demographic expansion. When such religious cults and fanatical religious sects start to have an increasing number of followers and generate social tensions, on the background of mass phenomenon, the risks to national security increase exponentially, because religious fanatics live in society, but they are still against society.

In this respect, Alexandre Deleyre (French writer and encyclopaedist) said about fanaticism and the behavior of fanatics since 1756 that they can be recognized as having attended the worship camp, but they are "full of the god that burns within them, spreading fear and delusion across the face of the earth. They carve up the world between them, and soon it is engulfed in flames" (Deleyre, 2016, p. 40). The author thus reveals the risk that this phenomenon will induce, even in a secularized society in which religiosity is and must be manifested only at an individual level and without affecting others. Former Rev. William H. Leach stated at the beginning of the twentieth century that: "fanaticism ... has, on the whole, shown itself incapable of organizing and maintaining a strong institution. Its individual type of mind is one of agitation rather than of construction". (Leach, 1919, p. 244).

To understand religious fanaticism and its repercussions on society, it must be noted that this is not a modern phenomenon but has manifested itself in the history of humanity, preserving the same forms of exteriorization. This phenomenon goes through the same stages, irrespective of the historical period, that is triggered by the congruence of several factors of socioeconomic-religious nature, thus generating in various forms the exacerbation of religious zeal and implicitly intolerance towards those who do not accept their visions religious. Josephus Flavius states that even since the Roman Empire was often used the term zealot for fanatics, a term borrowed from the Hebrew language and culture that was derived from the religious motivation of anti-Roman resistance. In this case of fantasy, the motivation was the one that led to every Jew an enthusiasm based on inner feelings (Josephus, 1981, p. 249). Religious fanaticism manifests itself in almost everywhere in the world and in many religions, but due to its negative influence on the Euro-American space, only those generated by Christianity and Islam will be considered. "Religious attitudes are generally acknowledged to be important elements in the social-psychological make-up of the individual. Despite the proliferation of empirical studies of religiosity and its correlates, the findings remain cloudy and curiously inconclusive" (Putney and Middleton, 1961, p. 285). Thus, we start the research on the assumption that the national and international security risks currently generated by religious fanatics have determined the most important impact in the present society, both psychologically and emotionally, who want nothing more than meeting the divinity they believe in.

\section{Fanaticism \\ 2. Determinants of Religious} The process of religious fanaticism has several evolutionary forms (from non-religiosity or intrinsic religiosity to indoctrination and later fanaticism), but those of confessional differences are noted. Here, religious conduct evolves from the non-violent form known as habituality (i.e., strict observance of religious norms) to intolerance and self-immolation as well as the rejection of dialogue with other religious cults. In this process a hateful attitude towards all those who do not share their doctrinal visions is developed, and finally there is violence in the name of the divinity they believe in. When a religious denomination comes to believe that it is a sacred duty to kill in the name of the divinity, any state is obliged to take measures to prevent such actions (Advocate of peace, 1869). 
Religious fanaticism is manifested and accentuated by the idea that in the end man is mortal, and daily activities within the community or professional begin to lose significance, shedding the inner and spiritual ones. These are of a defining nature for the future actions to which such an adept is to embrace, which embraces the doctrine that promotes religious excesses. For example, the Russians considered that their territorial expansion and inclusion of populations of another religion in the last three centuries did not constitute an impediment to the attainment of their own interests, based on their own characteristics of the Russian imperial authorities, compared to the American or British (what in the vision Russian is based on racism). Moreover, they considered that the opposition encountered in geographic areas with Muslim populations was not directed against expansion, but only against religious fanaticism (Sabol, 2017, pp. 235-244). Thus, they did not take into account the fact that this is the foundation of their existence for any adept of a confession, and at that moment there is a strong sense of self-defense. Russians, like the Americans, "believed they had a Christian duty to save the Sioux and the Kazakhs from the very fabrics of their social, cultural, economic, and political structures that kept them living a nomadic and barbaric life" (Sabol, 2017, p. 240).

In order for the members of a religious community to be enthralled, they must first be subjected to a process of religious indoctrination in order to assimilate the precepts and objectives of their cult. In this sense, Jonathan Edwards (reformist preacher, philosopher and Protestant congregationalist theologian (puritan)) affirmed that the Holy Scripture provides the natural right of men to obtain the benefits of divine intervention, but does not say their method of production (Smith, 1959, pp. 159-163). Affirmed that religious affairs that it is necessary to establish a link between the steps taken and the method used without which there is no certainty that the person is converted (Smith, 1959, pp. 159-163). Jonathan Edwards also concluded that the sacredness can not be verified actions of religious conversion or individual experiences, regardless of the order or procedures used for that purpose (Smith, 1959, pp. 159-163).

The emergence of religious fanaticism is determined by certain factors that have intersected at a certain time. This phenomenon is a reaction to certain historical events that extend over long periods of time. In this regard, Michael Polanyi (professor of chemistry and social sciences) says that "modern fanaticism is rooted in an extreme scepticism which can only be strengthened, not shaken, by further doses of universal doubt" (Polanyi, 2005, p. 314). This is confirmed by Leon R. Kass (physicist and scientist) who said: "thus, just as we must do battle with anti-modern fanaticism and barbaric disregard for human life, so we must avoid runaway scientism and the utopian project to remake humankind in our own image" (Kass, 2002). An indication of the determinants of religious fanaticism, in particular the evolution of feelings of isolation from society, as well as the exclusion of fanatics by society, both extremes being developed amid the imposition of ideas on individuals that in this context generates a strong repulsion towards members society.

\section{Fanaticism \\ 3. The Security Risks of Religious \\ Religious fanaticism will generate} risks to international security and, implicitly, to Romania's national security, because it is often manifested through violent actions. One side of this manifestation is that of transposing the phenomenon into violent actions called terrorist attacks, deeply influencing state security enforcement policies that seek to find solutions for identifying and 
counteracting violent extremist-religious manifestations. This approach is due to the development of religious fanaticism at the personal level according to the religious beliefs to which it relates, without exposing itself to the moment of strike, that is, the realization of a terrorist attack or suicide attack, which in many cases physically and mentally affect the civilian population. In this respect, Brian Michael Jenkins, Counselor to President RAND Corporation says that "but if the group portrait of the jihadists depicts an army of obedient religious fanatics ready to die for the cause of Islam, individual portraits underscore human diversity" (Jenkins, 2006a, p. 93), this being the reason why it is difficult to prevent such threats.

The same author says there is an explanation for the escalation of violence in the name of the divinity by reference to such religious groups within Islam, namely "terrorists themselves had become increasingly brutalized and more proficient. As terrorism became more commonplace, maintaining public attention and coercive power required escalation. ... political fanatics were giving way to religious fanatics who claimed God's mandate, allowing them to ignore ordinary moral constraints. These tendencies culminated in the attacks of September 11, 2001" (Jenkins, 2006b, p. 9). From here, we can observe the informal status of a non-state actor of groups and organizations based on religious fanaticism, as al-Qaeda has provoked strategic moves in international power relations. It can also see the risk to the national security of any state, generated by the absence of the good-bad, permissibleforbidden, accepted-unacceptable, legallyillegal, moral-immoral barrier. This barrier is abolished by an obvious factor, namely the exacerbated religious zeal, doubled by intolerance towards individuals/groups of individuals with other religious doctrinal options that they perceive as opponents, that is, permission to kill them in the name of the divinity. All Brian Michael Jenkins states the following: "the conviction that they had God's sanction freed religious fanatics from ordinary political or moral constraints" (Jenkins, 2002, p. 13).

A present risk is also the fact that secularized societies concentrate in public and private discourse in addressing ideas and problems from a secular and non-religious perspective, avoiding obstinately this confessional-doctrinal analysis when this is the primordial issue and not the risk analysis due to the role and place of the religious person within society. For example, in 2003, the French National Assembly was concerned about the integration of Muslims from a secular perspective, but the religious side was not a distinct chapter in this action (Fredette, 2014a, p. 37). As a result, this approach of religiosity in terms of laity has resulted in violence in the name of Allah in 2015 in Paris, in a society that believed that it was not possible to kill in the name of the divinity.

In order to better understand religious fanaticism, we must first address the issues regarding religious fanatics, because by their understanding we can really identify the constituent elements of this phenomenon. Thus, for example, jihadists are called fanatics, psychic laborers or criminals, in fact they are religious followers who oppose the modernity of the Western society and its culture, saying that it is a struggle to the extreme within the Islamic religion with the need for resilience against this accelerated progress (Aaron, 2008, p. 301). An eloquent example of the results of the religious fanaticism is that of the Albanians, about whom, in 1918, Charles Woods (formerly a US officer) wrote that "Whilst foreign propaganda has done a good deal to excite the religious feelings of the people, the Albanians are not as a rule religious fanatics" (Woods, 1918, p. 264). But after 70 years, these Muslim majority were involved in an inter-confessional war in former Yugoslav space against two rites, namely the Orthodox and Catholic, of the same religion, 
i.e., Christianity, based precisely on exacerbation of zeal religiously doubled into intolerance towards those of other beliefs.

\section{Consequences of Religious Fanaticism}

This phenomenon has generated a number of mutations in international power relations, due to the form of manifestation that is difficult to fit into certain action patterns. Against the backdrop of the strategic interests that every powerful state has at the global level, the opportunities offered by the fanatics of religious sects and cults for the achievement of their own state objectives are exploited. If we analyze the Al Qaeda organization, we can see that its members are resigned to the fact that the actions of the organization transcended their own existence because they submit to Allah's will, assuming their intentions as though they had obtained them (Jenkins, 2012, p. 11).

International power relations set up as a result of violent actions by religious fanatics have been modeled according to the interests of state actors. For example, Al-Qaeda leaders have clear pre-established goals that do not all relate to their own faith as their religious fanatics, for whom there is only divinity. They are aware of their own results, that is to say, the permanent state of fear, the fight against violent actions committed in the name of the divinity that have demanded a great deal of financial, material and human resources. The latter may be the reason why the clear purpose of American troops in such fighting actions of the phenomenon is not clear, and the conflict is not over yet (Jenkins, 2012). It is true, it will continue between professional militaries who have ultramodern combat techniques versus soldiers who consider themselves loyal to the divinity and who can hardly be recognized in society even by its members because, in their view, they only want to show devotion to their own fidelity, without much needing to do so. Moreover, in the context of the rebirth of the emphasis on religious aspects, such massifs can be amplified and extended. Michel Houellebecq (a French writer who launched on May 23, 2015 in Romania the controversial Roman "Submission", about the Islamization of France in 2022), considered that: "argue that however much we may object to the form of the current religious revival (Christian and Islamic fundamentalism) we may be obliged to accept that the return of religion is inevitabl" (Houellebecq, 2001, p. 166 apud Morrey, 2013, p. 143).

What is negative is that fanatical followers of a denomination broke the myth of military, economic and cultural invincibility, as Europeans believed to be protected from religious fanaticism, based on the idea that European society is a secularized one. Alain-Gerard Slama claimed in Le Figaro that "they are fanatics who believe they can bring jihad on French soil" (Fredette, 2014b, p. 136). The assertion was made in 2014, and on January 7, 2015, the Paris headquarters of satirical weekly Charlie Hebdo was attacked by Islamic religious fanatics who preferred to die in their vision for the revenge of the prophet MahSommed's honor. In this attack, 12 people died and the attackers (who turned out to be religious fanatics) were killed and not captured after two days because they preferred to die in the name of Allah rather than being caught by the infidels, i.e., the troops special police (Fredette, 2014b).

The power and influence of religious fanaticism on adherents of religious cults or religious sects or religious groups or organizations is so strong that even their own opinion formers within these denominations fail to generate reverberations to cause them to look at the surrounding world from all angles and not just by the exacerbation of religious zeal and intolerance towards others who do not share their visions. For example, scientists such as Omid Safi (American Oriental Studies Professor) and Tariq 
Ramadan (Professor of Contemporary Islamic Studies at the Oriental Studies Faculty of Oxford University) "identify fanatic fundamentalists as the real blasphemers, and call for Muslims to wrestle with their faith and to reject traditionalism that is embraced for the sake of traditionalism. Nevertheless, there are strong social tendencies, especially in the Salaf movement, in Indonesia, Afghanistan, Pakistan and Saudi Arabia, which resist critical debate, calling for the strict observance of Shari'a law" (Coleman and White, 2006, p. 6). This is confirmed by the magnitude of this religious phenomenon which, although a series of measures to mitigate it, could not yet be abolished (Van de Weyer, 2001, p. 9).

Religious fanaticism is not specific to Islam alone, but to Christian religion as well, revealed by the many victims of the exacerbation of religious zeal and intolerance towards those of another faith following the Crusades, the Inquisition, or the killing of thousands of French Calvinists (known as Huguenots) in 1572 and known as the Bartholomew Night Mass, and let's not forget about this kind of local action that has not been recorded by historiography and has also made many victims. In this respect, Ernst Bloch (German Marxist philosopher deceased in 1977) stated that "Fanaticism as an element of faith is found only in the two religions which started out from Moses, in Christianity and Islam. Warlike intolerance (certainly not rejected by Jesus, who had come to start a fire in the world and wished that it was already burning) has as its paragon Moses, who smashed the golden calf.' This 'peculiar, passionate, typically Islamic submission primarily presupposed the union of God's will with the monomania of God's champion", (Bloch, 1986, p. 1275).

In order to manage this phenomenon, it must first be understood, in particular, from the point of view of those who mastered it. It is difficult to count religious fanaticism precisely because of the confusion of basic religious principles. His adherents confuse the divine precepts of religious cults and religious sessions with the ideas extracted from the sacred books by religious leaders, to justify political, religious, economic or social goals. Also, we can not logically synthesize the elements that can affect the life of any person, regardless of faith. Regarding this, and especially to the understanding of the motivation of religious fanatics, Walter Laqueur (professor of the history of ideas) says that "religious fanaticism can also be interpreted as a defensive strategy to keep out foreign influencesand so preserve the purity of the believer's way of life. In our age, religious fanaticism frequently appears in secular form, or as a mixture of religion and politics. But there can be no doubt about its origins" (Laqueur, 2000, p. 99). So does Friedrich Nietzsche, that is, that, "fanatics are picturesque, mankind would rather see gestures than listen to reasons" (Nietzsche, 1895, p. 173).

\section{Conclusions}

We can say that the evolution of the international power relations over the last 15 years has been influenced and determined by state and non-state actors on the background of religious violence. It will also influence in the near future the ties between the states of the world and the actors based on religious fanaticism, because the excess zeal and intolerance towards those of other faith has transformed the adherents of religious cults and religious sects into true soldiers for whom there are no rules of war.

The effectiveness of these non-state actors is and will be quantified in the violence and fear induced in the name of the divinity, and achieving such goals is given by the low level of complexity in preparing violent actions, the only investment being made by religious leaders in to turn them into effective guided 
instruments. Achieving goals is thus done without high financial investment.

The issue of religious fanaticism is all the more complex as the followers' indoctrination is currently being done through the Internet, which often offers truncated teachings of the official variants of religious sects and cults. In this situation, it is hard to justify religious fanatics that they are wrong.
As a counter-reaction to Islamic religious fanaticism that has affected all the world's countries, there is also the possibility of generating Christian religious fanaticism based on the principle of reacting to another action, but also by the equilibrium of centrific forces at the level of modern society.

\section{REFERENCES}

Advocate of peace. (1869). Murder as a fanaticism. Advocate of Peace (1847-1884) 1, no. 11,162 .

Aaron, D. (2008). In Their Own Words: Voices of Jihad - Compilation and Commentary. Santa Monica, CA: RAND Corporation.

Burns, C., White E. \& White, K. (2006). Negotiating the Sacred in Multicultural Societies. In Negotiating the Sacred: Blasphemy and Sacrilege in a Multicultural Society, edited by Coleman Elizabeth Burns and White Kevin. Canberra: ANU Press.

Bloch, E. (1986). The Principle of Hope, vol. 3, trans. N. Plaice, S. Plaice and P. Knight. Oxford: Basil Blackwell.

Deleyre, A. (2016). Fanaticism from the Encyclopédie, 1756. In Tolerance: The Beacon of the Enlightenment, edited by Warman Caroline. Cambridge, UK: Open Book Publishers.

Fredette, J. (2014a). Elusive Citizenship: The Consequences of an Undesirable Public Identity, in Constructing Muslims in France: Discourse, Public Identity, and the Politics of Citizenship. Philadelphia: Temple University Press.

Fredette, J. (2014b). Housing: The Banlieues as a Geographic and Socially Constructed Place. In Constructing Muslims in France: Discourse, Public Identity, and the Politics of Citizenship. Philadelphia: Temple University Press.

Houellebecq, M. (2001). The Elementary Particles. New York: Knopf Doubleday Publishing Group, 166 apud Morrey, D. (2013) Science and Religion in Michel Houellebecq: Humanity and Its Aftermath. Liverpool University Press.

Jenkins, B. M. (2002). Understanding the Enemy, in Countering Al Qaeda: An Appreciation of the Situation and Suggestions for Strategy. Santa Monica, CA; Arlington, VA; Pittsburgh, PA: RAND Corporation.

Jenkins, B. M. (2006a). Knowing Our Enemy, in Unconquerable Nation: Knowing Our Enemy, Strengthening Ourselves. Santa Monica, CA; Arlington, VA; Pittsburgh, PA: RAND Corporation.

Jenkins, B. M. (2006b). How We Prevail in Unconquerable Nation: Knowing Our Enemy, Strengthening Ourselves. Santa Monica, CA; Arlington, VA; Pittsburgh, PA: RAND Corporation.

Jenkins, B. M. (2012). Al Qaeda in Its Third Decade: Irreversible Decline or Imminent Victory? Santa Monica, CA; Arlington, VA; Pittsburgh, PA: RAND Corporation.

Josephus (1981). The Jewish War, trans. G. A. Williamson, ed. and rev. E. M. Smallwood. London: Penguin.

Kass, L. R. (2002). The President's Council on Bioethics, Human cloning and human dignity: an ethical inquiry. Washington, DC July 2002, available at: https://biotech.law.lsu.edu/ research/pbc/about/chairman.html 
Laqueur, W. (2000). The New Terrorism - Fanaticism and the Arms of Mass Destruction. New York: Oxford University Press.

Leach, W. H. (1919). Religious fanaticism: asset or debit?. The Biblical World, Vol. 53, No. 3, 240-244.

Nietzsche, F. (1895). Twilight of the Idols and The Anti-Christ, trans. by R.J. Hollingdale, Baltimore, Penguin Books (1968), The Antichrist, section 54 (prepared for publication 1888, published 1895).

Polanyi, M. (2005). Personal Knowledge - Towards a Post-Critical Philosophy. London: Taylor \& Francis e-Library.

Putney, S., \& Middleton, R. (1961). Dimensions and Correlates of Religious Ideologies. Social Forces, vol. 39, no. 4, 285-290.

Sabol, S. (2017). Conclusion in The Touch of Civilization: Comparing American and Russian Internal Colonization. Boulder, Colorado: University Press of Colorado, 235-244.

Smith, J. E. (edited by), Edwards, J. (1959). Religious Affections in Jonathan Edwards Religious Affections, The Works of Jonathan Edwards, Vol. 2. New Haven: Yale University Press, 159-163.

Van de Weyer, R. (2001). Islamul și Occidentul - O nouă ordine politică și religioasă după 11 septembrie. București: Editura Allfa.

Woods, H. C. (1918). Albania and the Albanians. Geographical Review 5, no. 4, 257-273. 